JOURNAL OF SECURITY AND SUSTAINABILITY ISSUES

ISSN 2029-7017 print/ISSN 2029-7025 online

2020 March Volume 9 Number 3

https://doi.org/10.9770/jssi.2020.9.3(23)

Scopus

\title{
RISK MANAGEMENT, SUSTAINABLE GOVERNANCE IMPACT ON CORPORATE PERFORMANCE
}

\author{
Husaini $^{1^{*}}$, Kashan Pirzada ${ }^{3}$, Saiful ${ }^{2}$ \\ 1,2University of Bengkulu, Jl. W.R. Supratman, 38122, Bengkulu, Indonesia \\ ${ }^{3}$ Tunku Puteri Intan Safinaz School of Accountancy, Universiti Utara Malaysia, Kedah, Malaysia

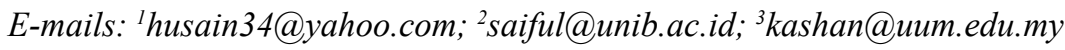

Received 23 March 2019; accepted 10 January 2020; published 30 March 2020

\begin{abstract}
The first objective of this study is to examine the relationship between the size of the Board of Directors and audit committee on the company's financial performance; the second is to test the size of the Board of Directors and the audit committee on the implementation of Enterprise Risk Management (ERM); the third is to examine the relationship of the application of ERM on the company's financial performance; , and fourth is to test the relationship of the size of the Board of Directors and audit committee on the company's financial performance when mediated by the adoption of ERM. The research sample is 70 firm-years Indonesian non-financial companies listed during 2013-2016. Structural equation Modeling (SEM) with the WarpPLS approach has been used for data analysis. The results showed that the size of the Board of Directors affected the company's financial performance, while the size of the audit committee did not affect the financial performance. The size of the Board of Directors and the audit committee influence the implementation of ERM. The application of ERM affects the company's financial performance. The application of ERM mediates partially the relationship between the size of the Board of Directors and the company's financial performance, but the application of ERM does not mediate the relationship between the size of the audit committee and the company's financial performance. The results of the study have implications for agency theory and resource dependence theory where a large Board of Directors is a solution to the problem of resources for supervision in improving organizational performance through the effective implementation of ERM.
\end{abstract}

Keywords: Company Financial Performance; Enterprise Risk Management; Board of Directors; Audit Committee.

Reference to this article should be made as follows: Husaini; Pirzada, K., Saiful, 2020. Risk Management, Sustainable Governance Impact on Corporate Performance. Journal of Security and Sustainability Issues, 9(3), 993-1004. https://doi.org/10.9770/jssi.2020.9.3(23)

JEL Classifications: M14, M41, M49

\section{Introduction}

The company's main goal is to increase the prosperity of shareholders. Management is always required to achieve certain performance standards as outlined in the performance contract. Business competition requires management to achieve performance above the industry average, therefore competitive advantage is needed to enable companies to compete in a demanding business environment. On the other hand, management's efforts to reach the agreed performance contract will always be accompanied by risk, the higher the target of achieving the desired performance by the company, the higher the level of risk exposure that will be faced. Various cases experienced by large companies such as Enron, WorldCom, Global Crossing, and Adelphia are examples of company failures in risk management. Reflecting on these failures, management must be able to implement an effective risk management system. The approach that is believed to be able to mitigate risk and manage risk holistically is by implementing Enterprise Risk Management (ERM). ERM is a new paradigm dealing with organizational risk that enables policymakers to focus on ways to improve risk management comprehensively with a holistic approach that goes beyond traditional silo-based risk management techniques (Beasley et al., 2005; Gordon et al., 2009; Viscelli et al., 2016; Petrenko et al., 2017; Suray et al, 2019; Nasr et al., 2019; 
Havierniková, Kordoš, 2019; Kordík, Kurilovská, 2019; Tarasova et al., 2018; Masood et al., 2019; Chehabeddine, Tvaronavičienè, 2020; Lincényi, Čársky, 2020), by using risk appetite, to determine risks that must be accepted, risks that must be reduced and risks that must be avoided by companies (Pagach and Warr, 2010). Recent developments in Corporate Governance have made ERM a key component of companies' management because the application of ERM is believed to be able to realize the company's goals in the long run and can be used as a tool to monitor agent performance by principals. Schroeck (2002) and Mafrolla et al. (2016) state that the application of ERM can overcome or reduce agency problems and improve company performance. Some researchers have proven that ERM can improve company performance such as Gordon et al. (2009), Hoyt and Lybenberg (2011), Florio and Leoni, (2016), but the opposite evidence, namely that ERM does not affect company performance, was found by Pagach and Warr (2010). While several other researchers have identified that the implementation of ERM is determined by many factors such as internal governance factors, namely the Board of Directors and audit committee. Desender (2007) argues that a large Board of Directors size adds opportunities to exchange information and expertise, thereby increasing the quality of ERM implementation. This is supported by the resource dependence theory according to which the most common solution to the inherent problems of the organization lies in the interdependence of resources to increase supervision that benefits each other's sources (Pfeffer and Salancik, 1978). Furthermore, Beasley et al. (2005) show that audit committees improve the quality of supervision over the implementation of ERM to reduce fraud and opportunistic behaviour of managers. On the other hand, empirical evidence first shows that the implementation of corporate governance can improve company performance, such as Belkhir (2009), Husaini and Saiful (2017), and Echeverri et al. (2019) who concluded that the size of a large Board of Directors can improve company performance. Likewise, the results of research undertaken by Reddy et al. (2010), Oradiet al. (2017), and Chiu, et al. (2019) revealed that the existence of an audit committee can reduce agency conflicts and improve company performance. Based on the argument above, this shows that there is a direct and indirect relationship between the size of the Board of Directors and the audit committee on the company's financial performance through the application of ERM. Therefore, first, this study contributes to the model of implementing ERM as a mediator between the supervisory function of the Board of Directors and the audit committee on the company's financial performance. Second, it provides support to agency theory and resource dependence theory (Suryani, 2018). Third, it adds empirical literature for the model of the application of ERM in Indonesia.

\section{Literature Review}

\subsection{Corporate Governance and Company Financial Performance}

Corporate governance has become an important pillar in ensuring the success of the company to remain sustainable. The Board of Directors and the audit committee are important mechanisms within this pillar. Agency theory indicates that a strong Board of Directors can reduce agency conflict and can align the interests of agents with the interests of the principals. In this case, the size of the Board determines the quality of supervision, especially in improving company performance. Jensen (1993) explains that companies with a slim board size will be more effective in carrying out supervision. In contrast, resource dependency theory supports the existence of large board sizes (Yahya \& Ghazali, 2017), where large board sizes guarantee the availability of external resources, enable the elaboration of knowledge, and the availability of skills that can strengthen the organization (Dalton et al., 1999). Several studies have confirmed the relationship between the Board of Directors size and company performance, showing that a large Board of Directors size can improve company performance (Belkhir, 2009; Husaini and Saiful, 2017; Echeverri et al., 2019). Based on the above review the first hypothesis of this study is as follows.

\section{H1: The Board of Directors positively influences the company's financial performance.}

The audit committee is a sub-committee of the Board of Directors as an important monitoring mechanism in corporate governance. The main function of the audit committee is to protect the interests of shareholders through financial supervision, internal control, the audit process, and risk management practices (Klein2002). Research on the relationship between audit committee and company performance shows that there is a signifi- 
cant positive relationship between audit committee and company performance despite using different proxies to measure performance, such as Oradi et al. (2017) proxied performance with ROA and Tobin's Q. Likewise the research of Chiu, et al. (2019) examined the voluntary adoption of audit committees on Tobin's Q, return on assets, and idiosyncratic risk, showing that audit committees, especially those controlled by families, enjoy better performance and lower risk (Kristanti, 2019). Chiu, et al. (2019) concluded that voluntary audit committee adoption can reduce agency conflicts and asymmetric information. Furthermore, the results of research by Reddy et al. (2010) concluded that large audit committees are more effective than smaller committees and help improve company performance. Therefore, the second hypothesis is as follows.

\section{H2: The audit committee has a positive effect on the company's financial performance.}

\subsection{Corporate Governance and Enterprise Risk Management}

As a pillar in the corporate governance of companies, the Board of Directors and audit committees have an important role in the company's supervision system, especially in overseeing the accuracy of the ERM implementation approach by management, including determining the company's risk appetite. Desender (2007) argues that a large number of board members add opportunities to exchange information and expertise, thereby increasing the quality of ERM. The results of the study of Wan Daud et al. (2011) show that there is a positive correlation between the quality of the Board of Directors at the level of ERM adoption in Malaysia. Gordon et al. (2009) concluded that the relationship between monitoring by the Board of Directors and the adoption of ERM is determined by the suitability of the ERM program and the level of monitoring by the Board of Directors. Based on the above thought, the third hypothesis is as follows.

\section{H3: The Board of Directors has a positive effect on the application of Enterprise Risk Management.}

On the other hand, the complexity of the risks faced by companies has resulted in changing the role of the audit committee which needs to add ERM to its agenda, thereby increasing its responsibilities (Burton, 2008). The audit committee is given explicit responsibility for overseeing ERM practices (Beasley, 2010; Viscelli et al., 2016), focusing on the challenges of the overall risk profile (Demidenko and McNutt, 2010), and has a coordinating system with the Board of Directors, management and auditors relating to risk management and financial reporting (Turley \& Zaman, 2004). This supervision allows the Board of Directors or managers to take risk mitigation strategies to maintain the effectiveness of the company's operations (Allini et al., 2016). The results of research conducted by Gottwald and Mensah (2015) show that there is a significant relationship between the existence of the audit committee and the level of ERM implementation. Likewise, the results of Husaini and Saiful (2019) show that the audit committee is one of the determinants of the effectiveness of the implementation of ERM in the banking industry in Indonesia (Arniati, 2019). Therefore, the fourth hypothesis is as follows.

\section{H4: The audit committee has a positive effect on the implementation of Enterprise Risk Management.}

\subsection{Enterprise Risk Management and Company Financial Performance}

According to Beasley et al. (2005), the application of ERM is a means to promote the company's operational performance and assist in making strategic decisions. ERM provides benefits for companies, such as reducing direct and indirect costs related to company finances, so that the application of ERM will affect revenue, namely by reducing variability through control of risk at the cost center and source of income. Therefore, the application of ERM improves performance because it helps companies to avoid loss, bankruptcy and reputation costs (Gordon et., 2009; Pagach and Warr, 2010). Lai and Samat (2011) conducted research using survey methods on 128 companies listed on the Malaysian stock exchange, the results of the study found that the implementation of ERM had a positive association in reducing the costs of financial difficulties (Firnanti, 2019), lowering external financing, improving the company's credit rating, obtaining rewards from the equity market, reduce information asymmetry, and reduce agency problems. Schroeck (2002) indicates that the application of ERM can reduce agency costs in the form of monitoring costs and improving company performance. Some research 
shows that the application of ERM can improve both financial performance and market performance of companies, such as the results of research conducted by Florio and Leoni (2016), Silva et al. (2018), Kommunuri et al. (2015); Hoyt and Lybenberg (2011), and Gordon et al. (2009). Research in Indonesia by Husaini and Saiful (2017) shows results that are consistent with some previous studies that the application of ERM can increase company value. However, some researchers found different results such as Pagach and Warr (2010) and Quon et al. (2012) who concluded that the application of ERM did not affect the company's financial performance. Based on the description above, the fifth hypothesis is as follows.

\section{H5: The application of Enterprise Risk Management has a positive effect on the company's financial performance.}

\subsection{Corporate Governance, Enterprise Risk Management, and Company Financial Performance}

Resource dependency theory states that resources can strengthen an organization (Dalton et al., 1999), thus a large Board of Directors and audit committee size can improve organizational performance. Some research results show there is a positive relationship between the Board of Directors size and company performance, for example, the research undertaken by Belkhir (2009), Husaini and Saiful (2017) and Echeverri et al. (2019). Furthermore, the effective application of ERM requires optimal supervision. The Board of Directors and audit committee have the competence to oversee the accuracy of the ERM implementation approach. Desender (2007) and Wan Daud et al. (2011) concluded that there was a positive relationship between the Board of Directors and the implementation of ERM, as well as the results of research by Gottwald and Mensah (2015) and Husaini and Saiful (2019) showed a positive relationship between the existence of the audit committee and the implementation of ERM. Furthermore, several studies have also shown that the application of ERM can improve company performance (Florio and Leoni, 2016; Silva et al., 2018; Kommunuri et al., 2015; Hoyt and Lybenberg, 2011; Gordon et al., 2009; and Husaini and Saiful, 2017). Based on several previous studies, there are indications that the influence of the Board of Directors and audit committees on company performance can be influenced directly and indirectly, or can be mediated, by ERM. Therefore, the sixth and seventh hypotheses are as follows.

H6: Implementation of Enterprise Risk Management mediates the relationship between the Board of Directors and the company's financial performance.

H7: The application of Enterprise Risk Management mediates the relationship between the audit committee and the company's financial performance.

\section{Research Methodology}

\subsection{Population, Sample and Data Source}

The population of this study is non-financial companies listed on the Indonesian Stock Exchange (IDX). Purposive sampling technique resulted in obtaining 670 observations during 2013-2016. This study uses secondary data, namely annual reports and financial reports obtained on IDX websites and the websites of each listed non-financial company.

\subsection{Variable, Measurement and Model}

The dependent variable in this study is the company's financial performance. The company's financial performance (CFP), measured by the ratio of ROAt +1 and $\mathrm{ROEt}+1$, is a measure of the company's effectiveness in generating future profits by utilizing its assets and equity. The independent variable consists of; 1) Board of Directors (BC), measured by the number of Board of Directors of the company and 2) audit committee (AC) measured by the number of audit committees. Then the mediating variable is Enterprise Risk Management 
(ERM) measured by the number of disclosures for each ERM component as an indicator, consisting of: internal environment (IE), objective setting (OS), event identification (EI), risk assessment (RA), risk response (RR), control activities (CA), information and communication (IC), and monitoring (MG). This study also includes the variables of sales growth (SG), asset growth (AG), company size (SZ) and Leverage (LV) in the research model to control the relationship of the dependent variable and the independent variable. This research model was developed based on several previous studies such as Gordon et al. (2009) and Florio and Leoni. (2016) by modifying ERM as an intervening variable and several related control variables.

The research model is as follows.

$$
\begin{aligned}
& \mathrm{CFP}_{\mathrm{it}+1}=\beta_{0}+\beta_{1} \mathrm{BS}_{\mathrm{it}}+\beta_{2} \mathrm{AC}_{\mathrm{it}}+\beta_{3} \mathrm{SG}_{\mathrm{it}}+\beta_{4} \mathrm{AG}_{\mathrm{it}}+\beta_{5} \mathrm{SZ}_{\mathrm{it}}+\beta_{6} \mathrm{LV}_{\mathrm{it}}+\varepsilon_{\mathrm{it}} \ldots \ldots \ldots \ldots \ldots \ldots \ldots \ldots \ldots \ldots \ldots \\
& \mathrm{ERM}_{\mathrm{it}}=\beta_{0}+\beta_{1} \mathrm{BS}_{\mathrm{it}}+\beta_{2} \mathrm{AC}_{\mathrm{it}}+\beta_{3} \mathrm{SG}_{\mathrm{it}}+\beta_{4} \mathrm{AG}_{\mathrm{it}}+\beta_{5} \mathrm{SZ}_{\mathrm{it}}+\beta_{6} \mathrm{LV}_{\mathrm{it}}+\varepsilon_{\mathrm{it}} \ldots \ldots \ldots \ldots \ldots \ldots \ldots \ldots \ldots \ldots \\
& \mathrm{CFP}_{\mathrm{it}+1}=\beta_{0}+\beta_{1} \mathrm{ERM}_{\mathrm{it}}+\beta_{2} \mathrm{BS}_{\mathrm{it}}+\beta_{3} \mathrm{AC}_{\mathrm{it}}+\beta_{4} \mathrm{SG}_{\mathrm{it}}+\beta_{5} \mathrm{AG}_{\mathrm{it}}+\beta_{6} \mathrm{SZ}_{\mathrm{it}}+\beta_{7} \mathrm{LV}_{\mathrm{it}}+\varepsilon_{\mathrm{it}}
\end{aligned}
$$

Data analysis to test the hypothesis has used structural equation modeling (SEM) with partial least squares (PLS) approach (WarpPLS), because SEM-PLS can analyze the measurement model reflective, formative, and latent variables even though only one indicator, without causing identification problems (Sholihin and Ratmono, 2013). Besides, SEM-PLS also does not require the assumption of a normal distribution (Sholihin et al., 2011). Testing ERM as an intervening variable was determined by the steps of Baron and Kenny (1986) and Hair et al. (2011).

\subsection{Validity and Reliability}

Before testing the structural relationships between latent variables, an outer model test is performed, which is known as the construct validity and reliability test. This study has two latent variables that require reflective measurements, namely the company's financial performance (CFP) and Enterprise Risk Management (ERM). Table 1 shows that loading of each indicator fulfills convergent validity even though there is loading below 0.70 , but the p-value is significant $(<0.05)$. According to Hair, et al. (2013) loading between 0.40-0.70 can be maintained if it has an impact on increasing the Average variance extracted (AVE). However, additional testing results indicate removal of loading below 0.70 does not increase AVE (test results are not presented in this paper).

Tabel 1. Combined loadings and cross-loadings

\begin{tabular}{|c|c|c|c|c|c|c|c|c|c|c|}
\hline Indikator & CFP & ERM & BC & AC & SG & AG & SZ & LV & SE & P value \\
\hline ROEt+1 & $(0.940)$ & 0.010 & 0.022 & -0.013 & -0.031 & 0.159 & -0.023 & 0.144 & 0.093 & $<0.001$ \\
\hline ROAt+1 & $(0.949)$ & -0.01 & -0.022 & 0.013 & 0.031 & -0.159 & 0.023 & -0.144 & 0.073 & $<0.001$ \\
\hline IE & -0.014 & $(0.760)$ & -0.027 & 0.084 & -0.046 & -0.076 & -0.143 & -0.057 & 0.033 & $<0.001$ \\
\hline OS & -0.004 & $(0.453)$ & -0.451 & 0.049 & 0.05 & 0.083 & 0.43 & -0.141 & 0.038 & $<0.001$ \\
\hline EI & -0.049 & $(0.881)$ & 0.103 & 0.013 & -0.005 & 0.024 & -0.033 & 0.064 & 0.026 & $<0.001$ \\
\hline RA & 0.058 & $(0.840)$ & 0.108 & -0.131 & -0.021 & 0.057 & 0.01 & 0.101 & 0.033 & $<0.001$ \\
\hline RR & 0.052 & $(0.860)$ & 0.094 & -0.057 & -0.019 & 0.058 & -0.013 & 0.111 & 0.033 & $<0.001$ \\
\hline CA & -0.047 & $(0.584)$ & 0.105 & 0.148 & 0.054 & -0.066 & -0.164 & -0.148 & 0.044 & $<0.001$ \\
\hline IC & -0.025 & $(0.621)$ & -0.113 & 0.012 & 0.045 & -0.086 & -0.081 & -0.084 & 0.029 & $<0.001$ \\
\hline MG & 0.012 & $(0.529)$ & -0.066 & -0.076 & -0.023 & -0.015 & 0.216 & 0.019 & 0.083 & $<0.001$ \\
\hline
\end{tabular}

Note: $\mathrm{P}$ values $<0.05$ are desirable for reflective indicators.

Table 2 shows the results of the reliability and collinearity tests, that the composite reliability and Cronbach's alpha values for CFP and ERM variables are above 0.70. Next AVE shows a value of 0.90 for the CFP variable and 0.50 for the ERM variable. These results fulfill the requirements of composite reliability and Cronbach's 
alpha $>0.70$ or have AVE values above 0.50 (Fornell and Lacker, 1981). Furthermore, the value of Full collinearity VIFs for all variables shows values below 3.3 so that it can be stated that the model is free from collinearity problems.

Table 2. Reliability and Collinearity

\begin{tabular}{|c|c|c|c|c|c|c|c|c|}
\hline & CFP & ERM & BC & AC & SG & AG & SZ & LV \\
\hline R-squared coeff. & 0.125 & 0.231 & & & & & & \\
\hline Composite reliability coeff. & 0.947 & 0.878 & 1.000 & 1.000 & 1.000 & 1.000 & 1.000 & 1.000 \\
\hline Cronbach's alpha coeff. & 0.889 & 0.837 & 1.000 & 1.000 & 1.000 & 1.000 & 1.000 & 1.000 \\
\hline Avg. variances extracted & 0.900 & 0.489 & 1.000 & 1.000 & 1.000 & 1.000 & 1.000 & 1.000 \\
\hline Full collinearity VIFs & 1.061 & 1.323 & 1.489 & 1.082 & 1.016 & 1.015 & 1.668 & 1.028 \\
\hline
\end{tabular}

\section{Results}

\subsection{Descriptive Statistics}

Table 3 shows the descriptive statistics of each variable, including the minimum, maximum, average and standard deviation values. Descriptive statistical data were used for testing models 1, 2 and 3, with a sample of 670 firm-years. The average value of the CFP variable is 0.101 , indicating that the average financial performance of the company is $10 \%$, with std. Deviation of $14 \%$ (above average), which means that the financial performance of the sample companies varies considerably. The average ERM of 0.495 and std. Deviation 0.095 , these results indicate the level of disclosure of ERM of companies in Indonesia around 49\%. The average size of the Board of Directors (BC) and the audit committee (AC) of the sample is 4 and 3 people, this data shows that the average sample company has met regulatory requirements in Indonesia.

Table 3. Descriptive data

\begin{tabular}{|c|c|c|c|c|}
\hline Variables & Minimum & Maximum & Mean & Std. Deviation \\
\hline CFP & -0.545 & 1.146 & 0.101 & 0.141 \\
\hline ERM & 0.269 & 0.759 & 0.495 & 0.095 \\
\hline BC & 2.000 & 11.000 & 4.318 & 1.756 \\
\hline AC & 2.000 & 7.000 & 3.096 & 0.413 \\
\hline SG & -4.067 & 1.510 & 0.022 & 0.435 \\
\hline AG & -7.172 & 0.998 & 0.098 & 0.341 \\
\hline SZ & 23.546 & 33.134 & 28.193 & 1.752 \\
\hline LV & 0.001 & 0.976 & 0.443 & 0.199 \\
\hline
\end{tabular}

\subsection{Hyphothesis Testing}

Before explaining the results of hypothesis testing, evaluation results are first presented that show the goodness of fit model, as follows. APC $=0.110, \mathrm{P}<0.001$; ARS $=0.178, \mathrm{P}<0.001$; and AVIF $=1.195$, Good if $<5$. These results indicate that the model criteria have been met where the APC and ARS are significant $<0.05$ and the AVIF value indicates a number $<0.05$. The following R2 for each model $(1,2$, and 3 ) is $12.20 \%, 23.10 \%$, and $12.50 \%$. The results of hypothesis testing are presented in Figure 1 and Table 4 below. 


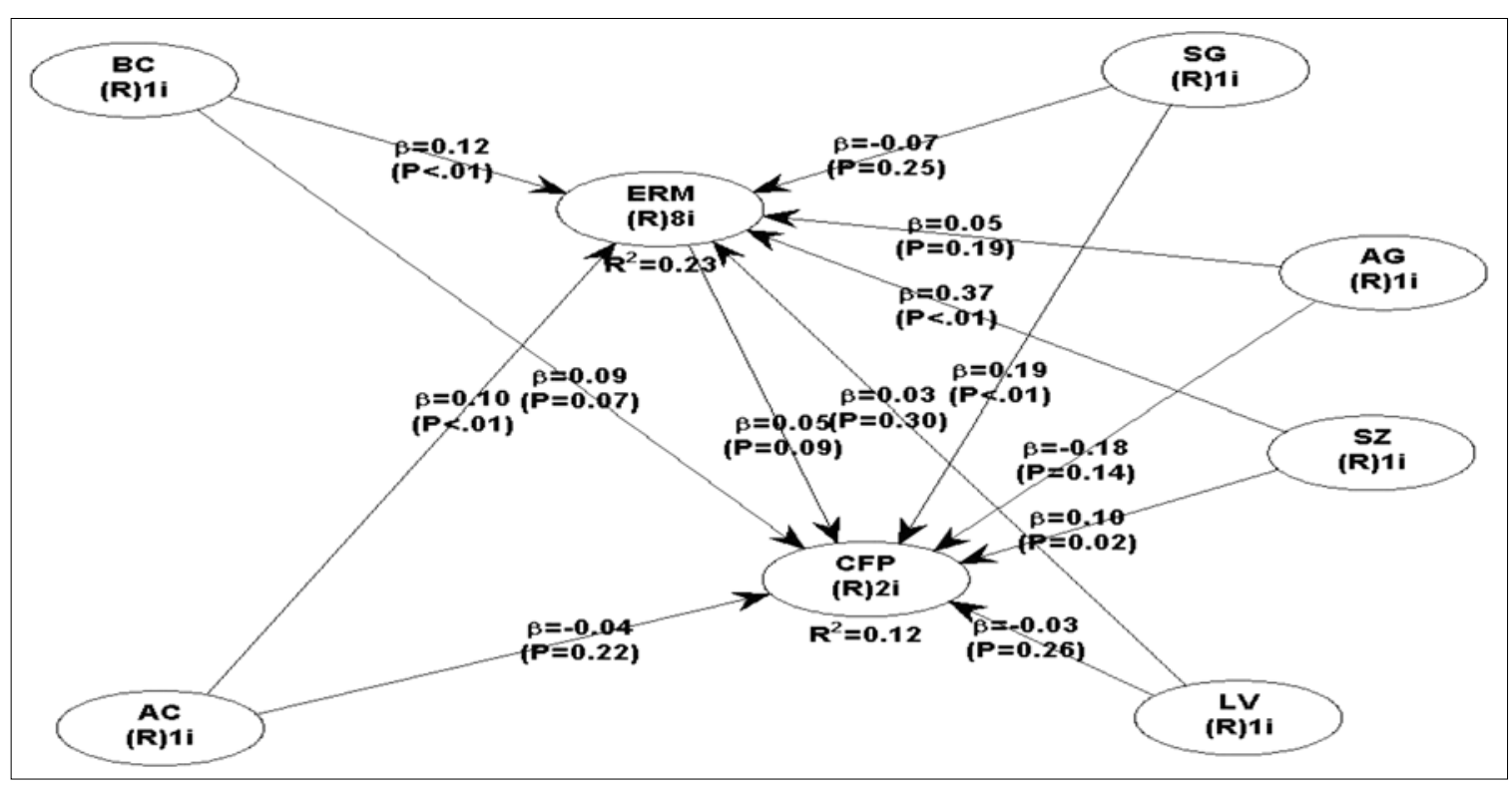

Figure 1. Model Structural

Table 4. The Results of Hypothesis Testing

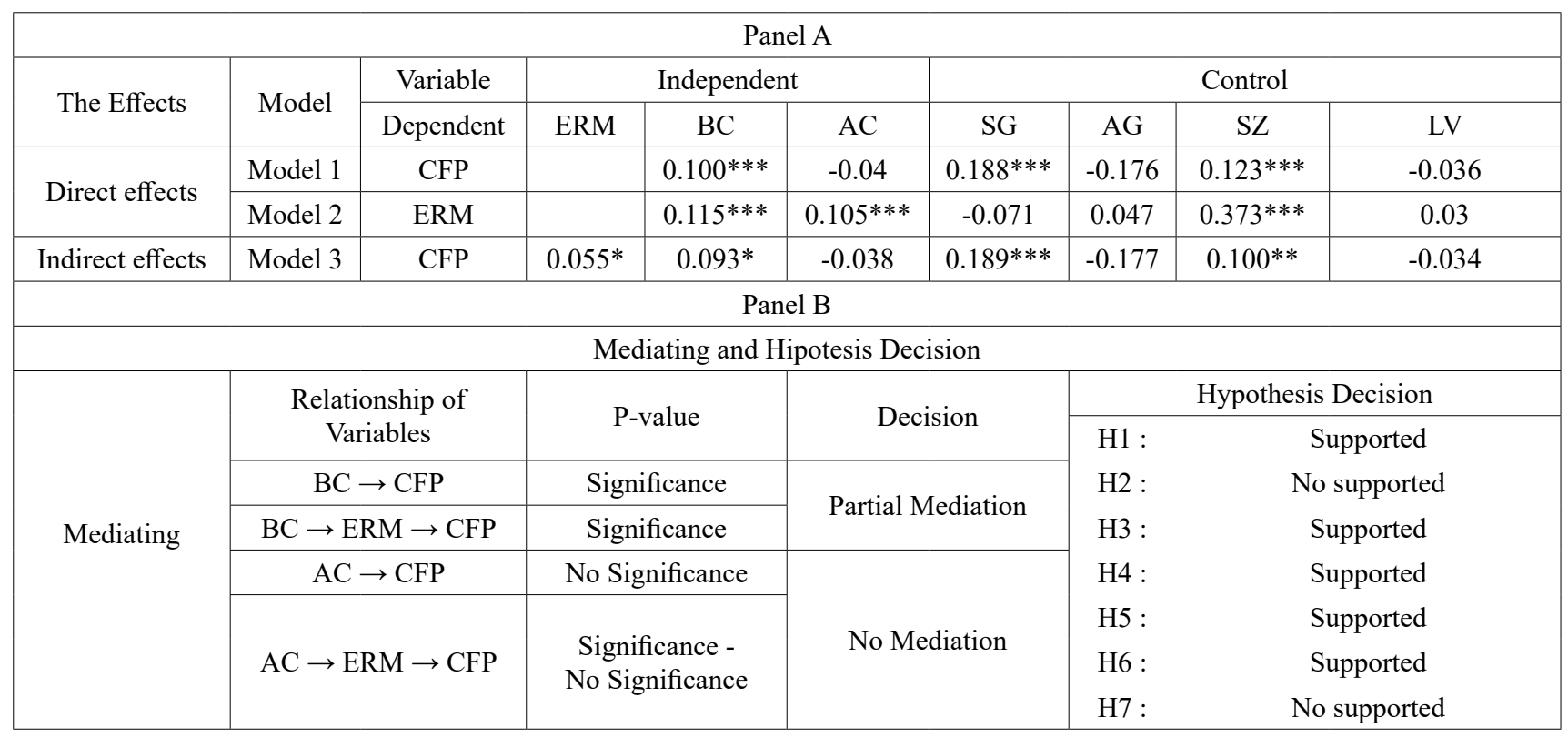

Notes: ${ }^{*} p<0.10 ; * * p<0.05 ; * * * p<0.01$

Table 4 Panel A presents the results of testing hypotheses 1-5. Hypothesis 1 shows that the $\mathrm{BC}$ has a positive effect on CFP $(\beta=0.097, p<0.10)$, this result shows that the greater the Board of Directors size, the company's financial performance will increase (H1 supported). Hypothesis 2 shows that AC has no effect on CFP $(\beta=-0.04, p>0.10)$, in which the size of the audit committee does not determine the company's financial performance ( $\mathrm{H} 2$ no supported). The results of testing hypotheses 3 and 4 show that the $\mathrm{BC}$ and $\mathrm{AC}$ variables have a positive effect on ERM with coefficients $(\beta=0.115, p<0.01 ; \beta=0.105, p<0.01)$. These results indicate that large $\mathrm{BC}$ and $\mathrm{AC}$ sizes increase the application of ERM (H3 and H4 supported). The results of testing of hypothesis 5 , indicate that there is a positive effect of ERM on CFP $(\beta=0.055, p<0.10)$. These results indicate that the implementation of ERM can improve the company's future financial performance (H5 supported). Table 4 Panel B presents the results of mediation testing (hypotheses 6 and 7). The test mediates ERM on the relationship of $\mathrm{BC}$ and $\mathrm{AC}$ on CFP, using the following Baron and Kenny (1986) steps; (a) There are Direct 
effects $\mathrm{BC}$ and $\mathrm{AC}$ must have a significant effect on CFP, but the result only $\mathrm{BC}$ has a significant effect on CFP (Hypothesis 1), while AC does not have an effect on CFP (Hypothesis 2). (b) simultaneous testing results show that BC has a significant effect on CFP; BC has a significant positive effect on ERM (Hypothesis 3), and ERM has a significant positive effect on CFP (Hypothesis 5). Based on these tests indicate that in the second step of testing the relationship between $\mathrm{BC}$ and CFP remains significant, but the coefficient decreases from $\beta=0.100$ (Model 1) to $\beta=0.093$ (Model 3). Therefore, according to the approach of Baron and Kenny (1986) and Hair et al. (2011), ERM partially mediates the relationship of BC to CFP (H6 supported). These results indicate that ERM is not the only mediator between $\mathrm{BC}$ and CFP, but there are still other mediating variables (Baron and Kenny, 1986). Conversely, ERM mediation in the relationship between AC and CFP is not supported (H7 no supported). Furthermore, the SZ control variable had a positive effect on ERM $(\beta=0.373, p<0.01)$, SG and SZ had a positive effect on CFP $(\beta=0.189, p<0.01 ; \beta=0.100, p<0.05)$, while AG and LV have no effect on both ERM and CFP.

\section{Discussion}

Agency theory indicates that a strong Board of Directors can reduce agency conflict and can align the interests of agents with the interests of the principals. In this case, the size of the Board of Directors largely determines the quality of supervision, especially in improving company performance. The results support the agency theory and resource dependence theory where a large Board of Directors is a solution to the problem of resources. This is especially for monitoring and improving organizational performance by implementing ERM effectively, so that the organization continues to survive. This is indicated by the positive relationship of Board of Directors size on the company's financial performance. The results of this study are in line with research undertaken by Belkhir (2009), Husaini and Saiful (2017) and Echeverri et al. (2019). These results also support the research of Desender (2007), Wan Daud et al. (2011), Gottwald and Mensah (2015) and Husaini and Saiful (2019) who concluded that the effective implementation of ERM requires optimal supervision by the Board of Directors and audit committees, both of these functions have the competence to oversee the accuracy of ERM implementation, so that large Boards of Directors and audit committees can improve the application of ERM. Furthermore, the results of this study also show that there is a positive relationship between the implementation of ERM and the company's financial performance, which means that the effective implementation of ERM will improve the company's financial performance; this is consistent with the statement (Gordon et., 2009; and Pagach and Warr, 2010) that with the implementation of company ERM, direct and indirect costs can be reduced, through controlling the cost centers and sources of income, so that it can improve company performance, and can help companies to avoid losses, bankruptcy, and reputation costs. Besides, the application of ERM can also reduce agency costs in the form of monitoring costs (Schroeck, 2002). These results are in line with the results of a study conducted by Florio and Leoni (2016), Silva et al. (2016), Kommunuri et al. (2015), Hoyt and Lybenberg (2011), Gordon et al. (2009), and Husaini and Saiful (2017) who concluded that company performance would improve when companies implemented ERM effectively and holistically.

\section{Conclusion}

Based on the results of the study, it can be concluded that the size of the Board of Directors can improve the company's financial performance; a large board of commissioners reflects an effective monitoring system to improve company performance. Likewise, the effective implementation of ERM requires optimal supervision by the Board of Directors and the audit committee. The effective implementation of ERM will also improve the company's financial performance. Furthermore, the application of ERM partially mediates the relationship between the size of the Board of Directors and the financial performance of the company, in this case, the function of the Board must continuously oversee the implementation of ERM, because it will have implications for improving company performance. The results of this study support agency theory and resource dependence theory where a large Board of Directors is a solution to resource problems for monitoring purposes, and to improve organizational performance through the effective application of ERM. In other words, the company's financial performance increases when the oversight function of the organization (the size of the Board of Directors is large) and the adoption of ERM increases. Therefore, the large size of the commissioners is a solution to 
strengthen the supervisory function by the board of commissioners and the audit committee in increasing the application of ERM, which impacts on the improvement of the company's financial performance.

\section{References}

Allini, A., Manes Rossi, F., \& Hussainey, K. (2016). The board's role in risk disclosure: an exploratory study of Italian listed stateowned enterprises. Public Money \& Management, 36(2), 113-120. https://doi.org/10.1080/09540962.2016.1118935.

Arniati, T., Puspita, D. A., Amin, A., \& Pirzada, K. (2019). The implementation of good corporate governance model and auditor independence in earnings' quality improvement. Entrepreneurship and Sustainability Issues, 7(1), 188-200. https://doi.org/10.9770/ jesi.2019.7.1(15)

Baron, R. M., \& Kenny, D. A. (1986). The moderator-mediator variable distinction in social psychological research: Conceptual, strategic, and statistical considerations. Journal of personality and social psychology, 51(6), 1173. https://psycnet.apa.org/buy/198713085-001

Beasley, M. S. (2010). Board and Audit Committee involvement in risk management oversight, embracing emerging expectations for risk management leadership. https://www.aicpa.org.

Beasley, M. S., Clune, R., \& Hermanson, D. R. (2005). Enterprise risk management: An empirical analysis of factors associated with the extent of implementation. Journal of accounting and public policy, 24(6), 521-531. https://doi.org/10.1016/j.jaccpubpol.2005.10.001

Belkhir, M. (2009). Board of directors' size and performance in the banking industry. International Journal of Managerial Finance, 5(2), 201-221. https://doi.org/10.1108/17439130910947903.

Burton, E. J. (2008). The audit committee: How should it handle ERM?. Journal of Corporate Accounting \& Finance, 19(4), 3-5. http:// dx.doi.org/10.1002/jcaf.20395.

Chehabeddine, M., Tvaronavičienè, M. 2020. Securing regional development. Insights into Regional Development, $2(1)$, 430-442. http://doi.org/10.9770/IRD.2020.2.1(3)

Chiu, J., Chung, H., \& Hung, S. C. (2019). Voluntary Adoption of Audit Committees, Ownership Structure and Firm Performance: Evidence from Taiwan. Emerging Markets Finance and Trade, 1-29. https://doi.org/10.1080/1540496X.2019.1635449

Dalton, D. R., Daily, C. M., Johnson, J. L., \& Ellstrand, A. E. (1999). Number of directors and financial performance: A meta-analysis. Academy of Management journal, 42(6), 674-686. https://doi.org/10.2307/256988

Daud, W. N. W., Haron, H., \& Ibrahim, D. N. (2011). The role of quality board of directors in enterprise risk management (ERM) practices: Evidence from binary logistic regression. International Journal of Business and Management, 6(12), 205. http://training-partners. co.id/tp-scpadm/file/16102012031609-capital\%20planing\%20(1).pdf

Demidenko, E., \& McNutt, P. (2010). The ethics of enterprise risk management as a key component of corporate governance. International Journal of Social Economics, 37(10), 802-815. http://dx.doi.org/10.1108/03068291011070462

Desender, K. (2011). On the determinants of enterprise risk management implementation. In Enterprise IT governance, business value and performance measurement (pp. 87-100). IGI Global. https://ssrn.com/abstract=1025982

Echeverri, H. H., Gaitan, S., Orozco, L. A., \& Echeverry, N. S. (2019). Board Characteristics, Compliance, and Firm Performance: Empirical Findings from Colombia, Latin American Business Review, 1-33, https://doi.org/10.1080/10978526.2018.1540935

Firnanti, F.; Pirzada, K.; Budiman. 2019. Company Characteristics, Corporate Governance, Audit Quality Impact on Earnings Management, Acc. Fin. Review 4 (2): 43 - 49. https://doi.org/10.35609/afr.2019.4.2(2)

Florio, C., \& Leoni, G. (2017). Enterprise risk management and firm performance: The Italian case. The British Accounting Review, 49(1), 56-74. https://doi.org/10.1016/j.bar.2016.08.003

Fornell, C., \& Larcker, D. F. (1981). Evaluating structural equation models with unobservable variables and measurement error. Journal of marketing research, 18(1), 39-50. https://doi.org/10.2307/3151312

Gordon, L. A., Loeb, M. P., \& Tseng, C. Y. (2009). Enterprise risk management and firm performance: A contingency perspective. Journal of Accounting and Public Policy, 28(4), 301-327. https://doi.org/10.1016/j.jaccpubpol.2009.06.006

Hair, J. F., Hult, G. T. M., Ringle, C., \& Sarstedt, M. (2013). A primer on partial least squares structural equation modeling (PLS-SEM). Los Angeles. Sage Publications. 
Hair, J. F., Ringle, C. M., \& Sarstedt, M. (2011). PLS-SEM: Indeed, a silver bullet. Journal of Marketing theory and Practice, 19(2), 139-152. https://doi.org/10.2753/MTP1069-6679190202

Havierniková, K., Kordoš, M. (2019). Selected risks perceived by SMEs related to sustainable entrepreneurship in case of engagement into cluster cooperation, Entrepreneurship and Sustainability Issues 6(4): 1680-1693. http://doi.org/10.9770/jesi.2019.6.4(9)

Husaini \& Saiful. (2019). The Determinant Factors of Enterprise Risk Management (ERM) And Credit Risk Consequence of Indonesian Banks, Academy of Accounting and Financial Studies Journal, Volume 23, Issue 4, Pp 1-15. https://www.abacademies.org/abstract/

Husaini, S. (2018). Enterprise Risk Management, Corporate Governance and Firm Value: Empirical Evidence from Indonesian Public Listed Companies. IJAME. http://managementjournal.info/index.php/IJAME/article/view/23

Jensen, M. C. (1993). The modern industrial revolution, exit, and the failure of internal control systems. the Journal of Finance, 48(3), 831-880. https://doi.org/10.1111/j.1540-6261.1993.tb04022.x.

Klein, A. (2002). Audit committee, board of director characteristics, and earnings management. Journal of accounting and economics, 33(3), 375-400. https://doi.org/10.1016/S0165-4101(02)00059-9

Kommunuri, J., Narayan, A., Wheaton, M., \& Jandug, L. (2015). Enterprise Risk Management and Firm Performance Empirical evidence from Vietnam. https://pdfs.semanticscholar.org/c038/5297a7ce919f4c9c702876250cd305f36cdc.pdf

Kordík, M. Kurilovská, L. (2019). Content of a IntraGroup Compliance Agreement as a risk mitigating factor Entrepreneurship and Sustainability Issues, 6(3), 1095-1104. http://doi.org/10.9770/jesi.2019.6.3(10)

Kristanti F. T; Rahayu S; Isynuwardhana D; 2019. Integrating Capital Structure, Financial and Non-Financial Performance: Distress Prediction of SMEs, Acc. Fin. Review 4 (2), 56-62. https://doi.org/10.35609/afr.2019.4.2(4)

Lai, F. W., \& A Samad, F. (2010). Enterprise risk management framework and the empirical determinants of its implementation. https:// www.researchgate.netpublication/278002258

Lincényi, M., Čársky, J. (2020). Policy trusts in public policy in the Slovak Republic. Insights into Regional Development, 2(1), 456468. http://doi.org/10.9770/IRD.2020.2.1(5)

Mafrolla, E., Matozza, F., \& D’Amico, E. (2016). Enterprise risk management in private firms: Does ownership structure matter?. Journal of Applied Business Research, 32(2), 671. https://doi.org/10.19030/jabr.v32i2.9603

Mensah, G., \& Gottwald, W. (2015). Enterprise risk management: Factors associated with effective implementation. Available at SSRN 2735096. http://ssrn.com/abstract=2735096

Nasr, A.K., Alaei, S., Bakhshi, F., Rasoulyan, F., Tayaran, H., Farahi, M. (2019). How enterprise risk management (erm) can affect on short-term and long-term firm performance: evidence from the Iranian banking system. Entrepreneurship and Sustainability Issues, 7(2), 1387-1403. http://doi.org/10.9770/jesi.2019.7.2(41)

Masood, O., Tvaronavičienè, M., Javaria, K. (2019). Impact of oil prices on stock return: evidence from G7 countries. Insights into Regional Development, 1(2), 129-137. https://doi.org/10.9770/ird.2019.1.2(4)

ORADI, J., LARI, D. M., \& SALARI, F. Z. (2017). Exploring the relationship between audit committee characteristics and the firm performance. https://www.sid.ir/en/journal/ViewPaper.aspx?id=577115

Pagach, D. P., \& Warr, R. S. (2010). The effects of enterprise risk management on firm performance. Available at SSRN 1155218. https:// dx.doi.org/10.2139/ssrn.1155218

Petrenko, E., Iskakov, N., Metsyk, O.; Khassanova, T. 2017. Ecosystem of entrepreneurship: risks related to loss of trust in stability of economic environment in Kazakhstan, Entrepreneurship and Sustainability Issues 5(1): 105-115. http://doi.org/10.9770/jesi.2017.5.1(8)

Pfeffer, J., \& Salancik, G. R. (1978). The External Control of Organizations: A Resource Dependence Perspective. The University of Illinois at Urbana-Champaign's Academy for Entrepreneurial Leadership Historical Research Reference in Entrepreneurship.

Quon, T. K., Zeghal, D., \& Maingot, M. (2012). Enterprise risk management and firm performance. Procedia-Social and Behavioral Sciences, 62, 263-267. https://doi.org/10.1016/j.sbspro.2012.09.042

Quon, T. K., Zeghal, D., \& Maingot, M. (2012). Enterprise risk management and firm performance. Procedia-Social and Behavioral Sciences, 62, 263-267. https://doi.org/10.1016/j.sbspro. 2012.09.042

Reddy, K., Locke, S., \& Scrimgeour, F. (2010). The efficacy of principle-based corporate governance practices and firm fi- 
nancial performance: An empirical investigation. International Journal of Managerial Finance, 6(3), 190-219. https://doi. org/10.1108/17439131011056224

Schroeck, G. (2002). Risk management and value creation in financial institutions (Vol. 155). John Wiley \& Sons.

Sholihin, M., Pike, R., Mangena, M., \& Li, J. (2011). Goal-setting participation and goal commitment: Examining the mediating roles of procedural fairness and interpersonal trust in a UK financial services organisation. The British Accounting Review, 43(2), 135-146. https://doi.org/10.1016/j.bar.2011.02.003

Silva, J. R., Silva, A. F. D., \& Chan, B. L. (2019). Enterprise Risk Management and Firm Value: Evidence from Brazil. Emerging Markets Finance and Trade, 55(3), 687-703. https://doi.org/10.1080/1540496X.2018.1460723

Solihin, M., \& Ratmono, D. (2013). SEM-PLS analysis with WarpPLS 3.0. Yogyakarta. Andi Publisher.

Suray, N., Karpenko, E., Dubovik, M., Shlyenov, Y., Sterlikov, F. (2019). Risk management at educational institution. Entrepreneurship and Sustainability Issues,7(2), 1171-1184. http://doi.org/10.9770/jesi.2019.7.1(26)

Suryani, A., \& Pirzada, K. (2018). Analysis of opportunistic behavior of management to company performance. Polish Journal of Management Studies, 18 (1), 379-388. https://doi.org/10.17512/pjms.2018.18.1.28

Tarasova, V.I., Mezdrykov, Y. V., Efimova, S.B., Fedotova, E.S., Dudenkov, D. A., Skachkova, R.V. (2018). Methodological provision for the assessment of audit risk during the audit of tax reporting, Enterpreneurship and Sustainability Issues, 6(1), 371-397. http://doi. org/10.9770/jesi.2018.6.1(23)

Turley, S., \& Zaman, M. (2004). The corporate governance effects of audit committees. Journal of management and governance, 8(3), 305-332. http://dx.doi.org/10.1007/s10997-004-1110-5

Viscelli, T. R., Beasley, M. S., \& Hermanson, D. R. (2016). Research insights about risk governance: Implications from a review of ERM research. SAGE Open, 6(4), 2158244016680230. https://doi.org/10.1177/2158244016680230

Yahya, F., \& Ghazali, Z. B. (2017). Effectiveness of board governance and dividend policy as alignment mechanisms to firm performance and CEO compensation. Cogent Business \& Management, 4(1), 1398124. http://dx.doi.org/DOI:10.1080/23311975.2017.1398 124

HUSAINI is an Associate Professor of Accounting in the Accounting Department of Bengkulu University. He works at the Bengkulu University Faculty of Economics and Business. He graduated from the Faculty of Economics of Syiah Kuala University, received his master's from Gadjah Mada University, and obtained a Ph.D. from Padjadjaran University. His work experience for 23 years taught at the graduate and post-graduate programs. His research fields are corporate governance, risk management, and auditing. He has published papers both in national and international journals and presented papers at various international conferences.

ORCID ID: https://orcid.org/0000-0001-6482-9844

Kashan PIRZADA is an Asst. Prof. of financial accounting at the Tunku Puteri Intan Safinaz School of Accountancy, Universiti Utara Malaysia. He has joined UUM after 12 years of research and teaching at the University of Malaya and Institute of Business Management. He has produced a number of research papers out of a funded project and has publications in international journals including the Elsevier Journal of Social and Behavioural Sciences, British Accounting and Finance; Polish Journal of Management Studies; Pertanika Journal of Social Sciences and Humanities, Entrepreneurship and Sustainability Issues and International Journal of Economics and Management. He has been a lead guest editor of the special issue for Elsevier Procedia of Social and Behavioural Sciences, Journal of Social Sciences and Humanities, and International Journal of Economics and Management. He continues researching on financial accounting issues in Both advanced capitalist countries and emerging/ less-developed countries. He is a regular speaker at research and professional forums, including the workshops and continues $\mathrm{PhD}$ supervision at UUM.

ORCID ID: https://orcid.org/0000-0003-1186-0631 
SAIFUL is an associate professor of financial accounting at the accounting department of the faculty of economics and business, Bengkulu University. He completed a bachelor's degree of accounting in faculty of economics and business, Syiah Kuala University. He obtained a master's degree of financial accounting from the Gadjah Mada University. He completed his philoshopy of doctoral in financial accounting and corporate governance in School of Management, Universiti Sains Malaysia. He has published many papers in various national and international journals in the fields of accounting, finance, risk management, corporate governance, and Islamic finance. He has also presented papers at a number of international conferences.

ORCID ID: https://orcid.org/0000-0002-3950-6696 